\title{
PEMBANGUNAN INDEKS HARGA HARTA TANAH WARISAN: KEDAI PRA- PERANG (PW-SPI) PULAU PINANG, MALAYSIA
}

\author{
MOHAMAD HAFIZ JAMALUDIN * \\ SURIATINI ISMAIL** \\ AINA EDAYU AHMAD*** \\ mdhafiz@jpph.gov.my*, suriatini@umk.edu.my**,aina@jpph.gov.my***
}

\begin{abstract}
Abstrak
Pengiktirafan Bandar George Town sebagai Tapak Warisan Dunia (TWD) UNESCO telah membawa kepada usaha pemuliharaan harta-harta warisan seperti pelaksanaan Pelan Pengurusan Warisan dan pewartaan Akta Warisan Kebangsaan 2005. Antara elemen warisan yang perlu dipelihara berkaitan harta tanah ialah kedai pra-perang. Kedai pra-perang merupakan kedai yang telah dibina dan dibangunkan sebelum perang dunia pertama pada tahun 1914. Ciri-ciri warisan yang ada pada kedai pra-perang perlu dipelihara dari segi ciri fizikalnya. Walau bagaimanapun, dengan arus pembangunan yang semakin pesat, semua usaha ini perlu penglibatan para pelabur dalam sektor harta tanah. Justeru, objektif kajian ini adalah untuk membangunkan Indeks Harga Kedai Pra-perang Pulau Pinang (PW-SPI) bagi mewujudkan indikator yang dapat membantu para pelabur dalam membuat keputusan pelaburan dalam pasaran harta tanah pra-perang. Kajian ini melibatkan pembangunan PW-SPI menggunakan Model Hedonik Laspeyres. PW-SPI yang dibangunkan membolehkan perbandingan secara grafik dibuat ke atas pergerakan harga harta tanah warisan di Pulau Penang. la menunjukkan bahawa bagi tempoh 2008-2014, harta tanah kedai pra-perang di Pulau Pinang mempunyai pertumbuhan harga yang lebih baik berbanding kedai bukan praperang. Kajian pertama di Malaysia berkaitan indeks harga harta tanah warisan ini boleh diulang dengan melibatkan kawasan geografi yang lebih luas. Ini kerana ia terbukti dapat membantu para pelabur dalam membuat keputusan pelaburan berkaitan harta tanah kedai praperang melalui perbandingan grafik.
\end{abstract}

Kata Kunci: Elemen Warisan, Indeks, Kedai Pra-perang, Model Hedonik Laspeyres, Pulau Pinang 


\title{
THE DEVELOPMENT OF HERITAGE PROPERTY PRICE INDEX: PRE-WAR SHOP (PW-SPI) PENANG, MALAYSIA
}

\author{
MOHAMAD HAFIZ JAMALUDIN \\ SURIATINI ISMAIL \\ AINA EDAYU AHMAD \\ mdhafiz@jpph.gov.my*,suriatini@umk.edu.my**,aina@jpph.gov.my ${ }^{* * *}$
}

\begin{abstract}
The recognition of George Town City as a World Heritage Site (TWD) UNESCO has led to the conservation efforts such as the implementation of the Heritage Management Plan and the publication of the National Heritage Act 2005. Among the elements of heritage that need to be preserved in relation to property are pre-war shops. Pre-war shops are shops that were built and developed before the first world war in 1914. The pre-war shops need to be preserved in terms of its physical features. However, with the rapid development trend, implementing this goal needs the involvement of investors in the real estate sector. Thus, the objective of this study is to develop the Penang Pre-war Shop Price Index (PW-SPI) in order to create an indicator that can help potential investors in making investment decisions related to the pre-war property market. PW-SPI was developed using the Laspeyres Hedonic Model. The developed PW-SPI has enabled a graphical comparison be made about heritage property price movement in Penang. It indicates that for the period 2008-2014 the pre-war shops in Penang had better price growth than the non pre-war shops. This earliest study of heritage property price index in Malaysia could be replicated to include data of other geographical areas. It is shown that it can help potential investors in making investment decision related to heritage property of shophouse through graphical comparison..
\end{abstract}

Keywords: Heritage Element, Index, Laspeyres Hedonic Model, Penang, Pre-war Shop

** Associate Professor at Faculty of Architecture and Ekistics, Universiti Malaysia Kelantan, Malaysia

*** Director at National Property Information Centre (NAPIC), Ministry of Finance, Malaysia 


\subsection{Pengenalan}

Usaha memelihara dan memulihara harta tanah warisan dengan mewujudkan Pelan Pengurusan Warisan yang diluluskan oleh Jawatankuasa Perancang Negeri, Pulau Pinang pada 12 Februari 2008 dan pewartaan Akta Warisan Kebangsaan 2005 atau Akta 645 adalah sangat penting bagi mengekalkan ciri-ciri budaya dan tradisional di Malaysia. Warisan secara amnya adalah sesuatu yang akan atau telah diwarisi yang mana akan melibatkan dua pihak iaitu generasi lepas dan generasi akan datang (Norliza, 2013). Harta tanah warisan merupakan salah satu faktor tarikan pelancong ke negara ini. Kecantikan dan keunikan bangunan lama menjadi daya tarikan pelancong kerana bangunan lama menyimpan sejarah dan peristiwa penting negara dan mempunyai nilai sentimental dan nilai budaya yang penting kepada generasi akan datang dalam mengenali sejarah negara. Ini menunjukkan bahawa kepentingan harta tanah warisan bagi menambah pendapatan negara dari segi sektor pelancongan.

Merujuk kepada kepentingan harta tanah warisan dan usaha-usaha yang dijalankan bagi memulihara harta tanah warisan, penglibatan daripada para pelabur khususnya dalam sektor harta tanah adalah penting bagi menjayakannya. Segala usaha memelihara dan memulihara harta tanah warisan melibatkan kos dan perbelanjaan yang besar (Osman, 2018), (Pagiola, 2001) \& (Reeve \& Shipley, 2014). Sebagai contoh, menurut Pagiola (2001) kos untuk memulihara bandar Split yang terletak di Split-Dalmatia County, Croatia yang telah wujud sejak tahun 1700 menelan belanja USD11.8 juta yang melibatkan kos pemeliharaan dan pemuliharaan tapak arkeologi dan bangunan warisan. Justeru penglibatan para pelabur baik dari dalam mahupun luar negara adalah amat penting bagi menjayakan usaha pemuliharaan ini. Walaubagaimanapun, matlamat utama para pelabur bagi melabur dalam portfolio pelaburan mereka tidak akan akan tercapai tanpa pulangan dan pertumbuhan modal yang lumayan (Murzyn-Kupisz, 2013). Mereka juga perlu mempertimbangkan beberapa perkara sebelum membuat keputusan dalam pelaburan mereka. Ini kerana menurut Boudry et al (2013) pembangunan indeks yang berkaitan harta tanah perdagangan adalah penting kerana indeks yang juga merupakan penanda aras pelaburan memainkan peranan penting dalam penilaian prestasi, keputusan melindungi nilai, dan strategi pelaburan keseluruhan.

Sehingga kini, kajian literatur menunjukkan masih belum ada indikator yang melibatkan indeks yang dapat membantu para pelabur membuat keputusan untuk melabur dalam sektor harta tanah perdagangan khususnya harta tanah warisan. Melalui kajian literatur, kajian-kajian lepas berkaitan harta tanah warisan di Malaysia adalah termasuk Fatin et al (2019), Junainah et al (2019), Normayuni et al (2019), Normayuni et al (2018), Junainah (2017), Junainah et al (2014a), Junainah et al (2014b). Namun begitu, tiada perbincangan khusus tentang indeks harga harta tanah telah diterbitkan. Indikator prestasi ini sangat penting bagi membantu para pelabur dalam membuat keputusan untuk melabur dalam harta tanah warisan. Dengan adanya penglibatan para pelabur dalam sektor harta tanah warisan, ia akan membantu Malaysia dalam mengekalkan ciri-ciri warisan selari dengan arus pembangunan yang pesat pembangunan. 
Oleh itu penulisan ini menumpukan kepada "Indeks Harga Kedai Pra-perang Pulau Pinang (PW-SPI)" yang dibangunkan bagi mewujudkan indikator tentang harta tanah warisan. Kajian ini memfokuskan kepada harta tanah kedai pra-perang di Pulau Pinang yang boleh dijadikan indikator bagi mengukur prestasi harta tanah warisan. Menurut Laporan Pasaran Harta 2014, jumlah stok Kedai Pra-Perang di Pulau Pinang adalah 4,816 unit iaitu kedua tertinggi berbanding dengan negeri Perak sebanyak 5,798 unit. Walaubagaimanapun dari segi bilangan pindah milik, harta tanah kedai praperang di Pulau Pinang mencatatkan bilangan pindah milik paling aktif iaitu sebanyak 184 unit yang mewakili $28 \%$ daripada keseluruhan jumlah Kedai Pra-Perang yang dipindah milik di seluruh Malaysia dengan nilai RM309,860,000.00 (NAPIC, 2014). Justeru, skop kajian yang menfokuskan kepada harta tanah kedai pra-perang di Pulau Pinang adalah sangat tepat dan sesuai.

Penulisan ini diteruskan dengan Bahagian 2 yang memberi pengenalan ringkas kepada indeks harta tanah di Malaysia. Bahagian 3 memberi tumpuan kepada kaedah yang kerap diguna dalam pembangunan indeks harta tanah iaitu kaedah pindahmilik. Bahagian 4 memperkenalkan data dan metodologi yang diguna dalam pembangunan indeks bagi kajian ini. Bahagian 5 memaparkan indeks yang dibangunkan iaitu PW-SPI beserta perbincangan. Bahagian $6 \& 7$ menutup penulisan dengan perbincangan serta membuat kesimpulan tentang indeks yang pertama dihasilkan bagi harta tanah kedai pra-perang di tapak warisan dunia di Pulau Pinang dan implikasinya.

\subsection{Indeks Harta Tanah}

Indeks dianggap sebagai penanda aras penting dan merupakan alat membuat keputusan dalam pasaran kewangan dan modal, dan juga dalam pasaran harta tanah (Farragher dan Savage, 2008). Dalam kematangan ekonomi, kepentingannya telah membawa kepada pembangunan indeks yang terkenal di peringkat antarabangsa terutamanya di Amerika Syarikat seperti National Council of Real Estate Investment Fiduciaries (NCREIF) Property Index (NPI), Moody's/REAL Commercial Property Index, Massachusetts Institute of Technology dan Center for Real Estate (MIT-CRE) Transaction-Based Index. Selain di Amerika Syarikat, terdapat juga indeks yang diterbitkan oleh Investment Property Databank (IPD) di United Kingdom yang dikenali sebagai IPD Index. Indeks ini menunjukkan prestasi harta tanah perdagangan dan industri yang mana dimiliki oleh institusi pelaburan dan syarikat harta tanah. Indeks juga dapat membantu pelabur dalam mengurus, membentuk strategi dan membuat keputusan untuk portfolio pelaburan mereka.

Di Malaysia, Indeks Harga Rumah Malaysia (IHRM) yang dibangunkan pada tahun 1997 dan merupakan indeks harta tanah pertama dibangunkan. IHRM dibangunkan dengan menggunakan model hedonik laspeyres, di mana purata harga rumah ditentukan berdasarkan kepada satu set ciri-ciri harta tanah manakala indeks dikira menggunakan formula pemberat Laspeyres (NAPIC, 2018). IHRM merupakan satusatunya indeks yang berkait secara langsung dengan harta tanah. Pada peringkat awal, penerimaan industri terhadap IHRM hanyalah semata-mata satu produk baru dalam pasaran. Selepas lebih daripada sedekad pengenalannya, IHRM dianggap sebagai salah satu daripada indikator makroekonomi yang penting kepada Bank 
Negara Malaysia (BNM) dan Kementerian Kewangan Malaysia (Ministry of Finance MOF) (MOF, 2017).

Lanjutan daripada pengenalan IHRM dan pentingnya indeks sebagai indikator dan penanda aras, NAPIC telah menerbitkan satu lagi indeks yang dikenali sebagai Indeks Sewaan Bangunan Pejabat Binaan Khas Wilayah Persekutuan Kuala Lumpur (Purpose Built Office Rental Index Wilayah Persekutuan Kuala Lumpur - PBO-RI WPKL). Indeks ini mula diterbitkan pada tahun 2011 dengan penerbitan secara sukuan dan menggunakan model hedonik laspeyres. PBO-RI indikator sewaan harta tanah perdagangan yang difokuskan kepada pejabat binaan khas di Wilayah Persekutuan Kuala Lumpur. PBO-RI dapat membantu pelabur harta tanah dan pemain di pasaran berkenaan keadaan semasa sewaan pejabat binaan khas di Wilayah Persekutuan Kuala Lumpur. Bermula pada tahun 2016, indeks ini telah dikembangkan kepada 3 negeri iaitu Selangor, Johor dan Pulau Pinang yang dikenali sebagai Indeks Sewaan Pejabat Binaan Khas Lembah Klang (WPKL dan Selangor), Johor Bahru dan George Town.

Keseluruhannya, PBORI merupakan satu-satunya indeks yang diterbitkan oleh NAPIC yang menunjukkan prestasi harta tanah perdagangan di Malaysia, namun ia lebih berkait dengan sewa. Begitu kajian yang dilaksanakan oleh Aina Edayu (2015) iaitu pembangunan indeks harga pejabat di Wilayah Persekutuan Kuala Lumpur yang mana ia melibatkan bangunan pejabat. Terdapat satu indeks yang berkait harta tanah warisan iaitu Indeks Harga Harta Tanah Pra-Perang Penang yang diterbitkan oleh Henry Butcher Penang. Hasil semakan dan kajian mendapati bahawa indeks ini bukan memaparkan indeks harga, tetapi ia hanya memaparkan harga harta tanah pra-perang di Penang yang dianalisa kepada harga sekaki persegi dan tidak melibatkan indeks. Justeru, kajian ini merupakan perintis kepada pembangunan indeks harta tanah perdagangan yang mengkhususkan kepada harta tanah kedai pra-perang di Pulau Pinang. Pembangunan indeks harta tanah di Malaysia ini diringkaskan seperti Jadual 1 di bawah:

Jadual 1: Ringkasan Pembangunan Indeks Harta Tanah Di Malaysia (Sumber: Penulis, 2020)

\begin{tabular}{|c|c|c|c|c|}
\hline Bil & Nama Indeks & Keterangan & $\begin{array}{c}\text { Elemen } \\
\text { Warisan }\end{array}$ & $\begin{array}{l}\text { Sumber } \\
\text { Rujukan }\end{array}$ \\
\hline 1. & $\begin{array}{l}\text { Indeks Harga } \\
\text { Rumah Malaysia } \\
\text { (IHRM) oleh } \\
\text { NAPIC } \\
\text { - Mengukur } \\
\text { prestasi dan } \\
\text { pergerakan } \\
\text { harga harta } \\
\text { tanah kediaman } \\
\text { di Malaysia }\end{array}$ & $\begin{array}{l}\frac{\text { Sektor }}{\text { Kediaman }} \\
\text { Pembahagian Indeks } \\
\text { Mengikut negeri, daerah \& } \\
\text { jenis kediaman. } \\
\text { Metodologi } \\
\text { Menggunakan pendekatan } \\
\text { berasaskan Pindah Milik } \\
\text { Harta Tanah dan } \\
\text { pembangunan indeks }\end{array}$ & Tiada & $\begin{array}{l}\text { NAPIC } \\
(2018)\end{array}$ \\
\hline
\end{tabular}




\begin{tabular}{|c|c|c|c|c|}
\hline & & $\begin{array}{l}\text { menggunakan Model } \\
\text { Regresi Berpemberat } \\
\text { Laspeyres }\end{array}$ & & \\
\hline 2. & $\begin{array}{l}\text { Residential } \\
\text { Property Index } \\
\text { (RPI) oleh } \\
\text { Malaysian Institute } \\
\text { of Economic } \\
\text { Research (MIER) } \\
\text { - la direka untuk } \\
\text { melengkapkan } \\
\text { kaji selidik } \\
\text { makro, iaitu } \\
\text { kajian keadaan } \\
\text { perniagaan dan } \\
\text { kajian sentiment } \\
\text { pengguna. }\end{array}$ & $\begin{array}{l}\frac{\text { Sektor }}{\text { Kediaman }} \\
\text { Pembahagian Indeks } \\
\text { Indek ini dijalankan dan } \\
\text { diterbitkan setiap suku } \\
\text { tahun, meliputi sejumlah } 780 \\
\text { pemaju perumahan. } \\
\text { Metodologi } \\
\text { Berasaskan Soal Selidik }\end{array}$ & Tiada & $\begin{array}{c}\text { MIER } \\
(2003)\end{array}$ \\
\hline 3. & $\begin{array}{l}\text { Indeks Harta } \\
\text { Tanah oleh Bursa } \\
\text { Malaysia } \\
\text { - Mengukur } \\
\text { prestasi syarikat } \\
\text { harta tanah di } \\
\text { bawahnya dan } \\
\text { bukan prestasi } \\
\text { harta tanah atau } \\
\text { pelaburan yang } \\
\text { dibuat oleh } \\
\text { suarikat harta } \\
\text { tanah tersebut. }\end{array}$ & $\begin{array}{l}\frac{\text { Sektor }}{\text { Prestasi syarikat }} \\
\text { Metodologi } \\
\text { Berasaskan prestasi syarikat }\end{array}$ & Tiada & $\begin{array}{c}\text { Bursa } \\
(2014)\end{array}$ \\
\hline 4. & $\begin{array}{l}\text { Indeks Sewaan } \\
\text { Pejabat Binaan } \\
\text { Khas Wilayah } \\
\text { Persekutuan } \\
\text { Kuala Lumpur } \\
\text { - Mengukur } \\
\text { prestasi dan } \\
\text { pergerakan } \\
\text { harga sewa } \\
\text { pejabat di Kuala } \\
\text { Lumpur. }\end{array}$ & $\begin{array}{l}\frac{\text { Sektor }}{\text { Pejabat }} \\
\text { Pembahagian Indeks } \\
\text { Kuala Lumpur City Centre - } \\
\text { Golden Triangle (KLCC-GT), } \\
\text { Central Business District } \\
\text { (CBD), Within City Centre } \\
\text { (WCC) \& Suburban } \\
\text { Metodologi } \\
\text { Menggunakan pendekatan } \\
\text { berasaskan Pindah Milik dan } \\
\text { pembangunan indeks } \\
\text { menggunakan Model } \\
\text { Regresi Laspeyres }\end{array}$ & Tiada & $\begin{array}{l}\text { NAPIC } \\
(2018)\end{array}$ \\
\hline
\end{tabular}




\begin{tabular}{|c|c|c|c|c|}
\hline 5. & $\begin{array}{l}\text { Kuala Lumpur } \\
\text { Office Price Index } \\
\text { (KL-OPI) } \\
\text { - Mengukur } \\
\text { prestasi dan } \\
\text { pergerakan } \\
\text { harga harta } \\
\text { tanah pejabat di } \\
\text { Kuala Lumpur }\end{array}$ & $\begin{array}{l}\text { Sektor } \\
\text { Pejabat } \\
\text { Pembahagian Indeks } \\
\text { Kuala Lumpur } \\
\text { Metodologi } \\
\text { - Berasaskan pindah milik } \\
\text { - Model regresi } \\
\text { - Perbandingan antara } \\
\text { (Konvensional, Laspeyres } \\
\text { dan Chained) }\end{array}$ & Tiada & $\begin{array}{c}\text { Aina Edayu } \\
\text { (2015) }\end{array}$ \\
\hline 6. & $\begin{array}{l}\text { Indeks Harga } \\
\text { Harta Tanah Pra- } \\
\text { perang di Penang } \\
\text { oleh Henry } \\
\text { Butcher } \\
\text { - Mengukur } \\
\text { prestasi dan } \\
\text { pergerakan } \\
\text { harga harta } \\
\text { tanah pra- } \\
\text { perang di } \\
\text { Penang. } \\
\text { - Penerbitan ini } \\
\text { tidak melibatkan } \\
\text { indeks, tetapi } \\
\text { hanya } \\
\text { memaparkan } \\
\text { harga harta } \\
\text { tanah pra- } \\
\text { perang yang } \\
\text { dianalisa kepada } \\
\text { harga sekaki } \\
\text { persegi. }\end{array}$ & $\begin{array}{l}\frac{\text { Sektor }}{\text { Kedai Pra-perang }} \\
\text { Pembahagian Indeks } \\
\text { Pulau Pinang } \\
\text { Metodologi } \\
\text { - Berasaskan pindah milik. } \\
\text { - Analisa harga sekaki } \\
\text { persegi }\end{array}$ & Ada & $\begin{array}{c}\text { Henry } \\
\text { Butcher } \\
\text { Malaysia } \\
\text { (Penang) } \\
(2016)\end{array}$ \\
\hline
\end{tabular}

\subsection{Pembangunan Indeks Harta Tanah Berasaskan Kaedah Pindah Milik}

Pendekatan pembangunan indeks harta tanah berasaskan pindah milik harta merupakan pendekatan yang telah lama digunakan (Bailey dll., 1963; Rosen, 1974; Quigley, 1995; Francke, 2010). la sesuai digunakan apabila data pindah milik harta tanah adalah banyak dan menyeluruh. Pendekatan pembangunan indeks harta tanah 
menggunakan kaedah ini boleh dibahagikan kepada model jualan ulangan (repeat sales), model harga hedonik dan model hibrid.

\subsection{Model Jualan Ulangan (Repeat Sales)}

Model jualan ulangan adalah satu teknik ekonometrik yang dibangunkan oleh Bailey dll. (1963), di mana harga pindah milik harta tanah yang sama diperhatikan bagi dua tempoh berdasarkan kepada andaian bahawa kualiti harta kekal berterusan sepanjang tempoh masa tersebut. Bailey dll. (1963) dan Case dan Shiller (1987) merupakan perintis yang menggunakan kaedah jualan ulangan dalam sektor kediaman. Model ini sering digunakan untuk sektor kediaman kerana pindah miliknya yang banyak dan kerap kali berlaku. Walau bagaimanapun penggunaannya dalam pembangunan indeks harta tanah perdagangan adalah kurang sesuai kerana kurangnya data pindah milik dan sukar untuk memperolehi harta tanah perdangangan yang dipindah milik dalam tempoh yang singkat.

Gatzlaff dan Haurin (1998) telah menjalankan kajian terhadap pasaran perdagangan di Florida dan mendapati bahawa indeks jualan ulangan mencatatkan pergerakan harga yang lebih realistik berbanding indeks NCREIF yang menggunakan asas penilaian. Disebabkan kemajuan modal kewangan dalam pasaran Amerika Syarikat, Geltner dan Pollakowski (2006) telah mengambil usaha membangunkan terbitan untuk merancakkan pindah milik harga harta tanah perdagangan pada masa hadapan. Matlamatnya adalah untuk menyediakan indeks yang lebih praktikal dan berguna dalam terbitan pasaran. Geltner dan Pollakowski (2006) dan Bokhari dan Geltner (2010) telah membangunakan indeks kebangsaan untuk Amerika Syarikat dan 15 subkawasan yang menjangkau dari tahun 2001 hingga kini.

\subsection{Model Hedonik}

Teknik hedonik merupakan pendekatan yang berasaskan pindah milik dan telah digunakan lebih daripada 70 tahun yang lalu (Aina Edayu, 2015). Dalam teknik hedonik, harga pindah milik digunakan sebagai fungsi ciri-ciri harta tanah seperti umur, lokasi, luas tanah, luas bangunan, keadaan bangunan dan lain-lain. Berbeza dengan model yang dibincangkan sebelum ini, model hedonik tidak memerlukan jualan ulangan daripada harta tanah yang sama. Walau bagaimanapun, model ini perlu mengambil kira ciri-ciri harta serta ciriciri ruang (Haurin, 2003).

Pada prinsipnya, teknik ini boleh dilaksanakan sekiranya semua ciri-ciri yang mempengaruhi nilai harta tanah boleh diperolehi untuk mengawal perbezaan kualiti ciri-ciri harta tanah yang dipindah milik pada masa tertentu (Fisher dll., 2007). Perlaksanaan kaedah ini adalah lebih relevan jika kualiti semua pemboleh ubah hedonik boleh diperolehi dan maklumatnya lengkap tersedia. Teknik hedonik menawarkan mekanisme harga alternatif yang boleh meningkatkan indeks yang dihasilkan di peringkat kebangsaan.

Teknik hedonik mempunyai asas teori yang kuat (Griliches 1971; Rosen 1974) 
dan penggunaannya dapat mengawal perubahan komposisi dan kualiti pada satu-satu harta tanah. Kelebihan utama penggunaan hedonik secara umum adalah ia menyediakan anggaran langsung perubahan harga sebenar dan boleh pada dasarnya mengawal perubahan dalam komposisi dan kualiti harta tanah yang dijual.

Munneke dan Slade (2001) menggunakan kepelbagaian dalam teknik hedonik dalam kajian mereka dengan menggunakan tiga teknik parameter masa yang berbeza-beza iaitu hedonik 'chained', hedonik 'Laspeyres' dan hedonik 'Paasche'. Tujuan kajian mereka adalah untuk menilai teknik hedonik yang paling boleh dipercayai terhadap model pasaran pejabat dengan menggunakan nisbah Signal-to-Noise sebagai alat ukuran. Ini adalah asas yang digunakan dalam kajian oleh Aina Edayu (2015).

\subsection{Model Hibrid}

Pendekatan berasaskan pindah milik seterusnya adalah model hibrid, yang pada asasnya menggabungkan dan mengubah ciri-ciri model jualan ulangan dan model harga hedonik. Model ini dibangunkan oleh Quigley (1995), pada dasarnya melibatkan gabungan jualan ulangan dan model hedonic dan mengenakan kekangan bahawa perubahan anggaran harga adalah sama dalam kedua-dua model tersebut. Walaupun begitu, Quigley (1995) tidak melihat sebarang kelebihan yang jelas dalam menggunakan model hibrid berbanding model hedonik.

Bagi tujuan pembangunan PW-SPI, model harga hedonik adalah lebih bersesuaian untuk digunakan berbanding model jualan ulangan dan hibrid. Ini kerana data pindah milik yang digunakan dalam pembangunan PW-SPI mempunyai kepelbagaian ciri-ciri yang menerangkan sifat sesuatu harta tanah. Selain itu juga, harta tanah perdagangan seperti kedai pra-perang kurang dipindah milik di pasaran berbanding kediaman dan sukar untuk memperolehi harta tanah perdangangan sama yang dipindah milik dalam tempoh yang singkat untuk melaksanakan model jualan ulangan.

\subsection{Data dan Metodologi}

Secara keseluruhan, metodologi kajian ini adalah menggunakan pendekatan kuantitatif. Ini kerana kajian ini melibatkan ujian statistik yang dijadikan sebagai usaha untuk menerangkan, menjelaskan atau mencari perhubungan antara pemboleh ubah-pemboleh ubah seperti yang dipaparkan pada Jadual 2 .

\subsection{Gambaran Kawasan Kajian}

Kajian ini telah memilih negeri Pulau Pinang sebagai kawasan kajian. Pulau Pinang yang berkeluasan $1,048 \mathrm{~km}^{2}$ terdiri daripada bahagian pulau dan juga tanah besar yang dikenali sebagai Seberang Perai. Keluasan kawasan pulau adalah $285 \mathrm{~km}^{2}$ yang terpisah sepenuhnya daripada Seberang Perai. Bahagian pulau terdapat dua daerah iaitu Timor Laut dan Barat Daya. Di daerah Timor Laut terletaknya ibu negeri Pulau Pinang iaitu Bandar George Town yang telah diiktiraf 
oleh oleh UNESCO sebagai Tapak Warisan Dunia pada tahun 2008. Pada bahagian Seberang Perai pula terdapat 3 daerah iaitu Seberang Perai Utara, Seberang Perai Tengah dan Seberang Perai Selatan. Kajian ini mencakupi data pindah milik harta tanah kedai pra-perang yang terdapat pada kelima-lima daerah yang terdapat di Pulau Pinang.

\subsection{Sumber Data}

Sumber data yang digunakan dalam kajian ini adalah diperolehi daripada pangkalan data NAPIC. Sumber data yang diperolehi melalui NAPIC adalah pindah milik jual beli harta tanah. Pindah milik jual beli yang direkodkan di pengkalan data NAPIC seperti yang diketahui merupakan data yang komprehensif dan meluas yang merangkumi pengkalan data di seluruh negara.

Data pindah milik yang digunakan untuk membangunkan PW-SPI adalah sama seperti yang digunakan untuk membangunkan Moody Commercial Property Price Index, di mana sumber data diperolehi daripada Real Capital Analytics Inc. Walau bagaimanapun, ia hanya merekodkan pindah milik harta tanah yang bernilai kurang daripada USD 2.50 juta sahaja. Tidak seperti pengkalan data NAPIC, data yang direkodkan adalah lebih luas dan tidak mengira nilai harta tanah tersebut. Sumber data ini adalah yang digunakan dalam membangunkan IHRM, maka penggunan sumber data ini adalah bertepatan dan rasional bagi membangunkan PW-SPI.

Data pindah milik diperolehi daripada Lembaga Hasil Dalam Negeri (LHDN) yang menghantar permohonan ke setiap cawangan Jabatan Penilaian \& Perkhidmatan Harta (JPPH) secara dalam talian di mana permohonan yang dihantar termasuk rekod pindah milik harta tanah. Peranan LHDN ini adalah sebagai agensi pemohon yang mengenakan duti setem kepada pembeli bagi setiap transaksi pindah milik harta tanah. LHDN secara tidak langsung menjadi pembekal data pindah milik kepada JPPH. NAPIC yang merupakan sebahagian daripada JPPH seterusnya merekodkan data ini dalam pengkalan data NAPIC.

Data pindah milik yang diperoleh daripada sistem pengkalan data PRISM NAPIC mengandungi maklumat yang boleh dikategorikan kepada 3 iaitu maklumat fizikal, lokasi dan pindah milik. Ketiga-tiga maklumat ini sangat penting bagi menentukan pemboleh ubah yang signifikan dan bagi menentukan pemilihan sampel. Pemboleh ubah ini terdiri daripada kombinasi data nisbah, ordinal dan nominal. Keterangan pemboleh ubah yang digunakan dalam penjanaan indeks ini adalah seperti pada Jadual 2 di bawah: 
Jadual 2: Keterangan Pemboleh ubah

(Sumber: NAPIC, 2014)

\begin{tabular}{|c|c|c|c|c|}
\hline \multicolumn{2}{|c|}{ Pemboleh ubah } & Keterangan & Ukuran & Singkatan \\
\hline \multirow{4}{*}{ A. Fizikal } & $\begin{array}{l}\text { 1. Bilangan } \\
\text { tingkat }\end{array}$ & $\begin{array}{l}\text { Menunjukkan bilangan } \\
\text { tingkat kedai }\end{array}$ & $\begin{array}{l}\text { Nisbah - diukur } \\
\text { dalam nombor }\end{array}$ & A_TINGKAT \\
\hline & $\begin{array}{l}\text { 2. Luas } \\
\text { Tanah }\end{array}$ & Saiz keluasan tanah & $\begin{array}{l}\text { Nisbah - diukur } \\
\text { dalam meter } \\
\text { persegi }\end{array}$ & A_LTNH \\
\hline & $\begin{array}{l}\text { 3. Luas } \\
\text { Bangunan }\end{array}$ & Saiz keluasan bangunan & $\begin{array}{l}\text { Nisbah - diukur } \\
\text { dalam meter } \\
\text { persegi }\end{array}$ & A_LBGN \\
\hline & $\begin{array}{l}\text { 4. Tahun } \\
\text { Bangunan } \\
\text { Siap }\end{array}$ & $\begin{array}{l}\text { Tahun dimana Sijil Layak } \\
\text { Menduduki dikeluarkan } \\
\text { kepada harta tanah. }\end{array}$ & Nisbah - tahun & A_UMUR \\
\hline \multirow[b]{2}{*}{ B. Lokasi } & 1. Daerah & $\begin{array}{l}\text { Menerangkan kedudukan } \\
\text { kedai di satu-satu daerah. } \\
\text { Terdapat } 5 \text { daerah di Pulau } \\
\text { Pinang. }\end{array}$ & Nominal & - \\
\hline & 2. Mukim & $\begin{array}{l}\text { Menerangkan kedudukan } \\
\text { kedai di satu-satu mukim. } \\
\text { Terdapat } 72 \text { mukim } \\
\text { keseluruhannya di Pulau } \\
\text { Pinang. Terdapat satu mukim } \\
\text { iaitu George Town untuk } \\
\text { mengukur kesan Tapak } \\
\text { Warisan Dunia }\end{array}$ & Nominal & DM154 \\
\hline
\end{tabular}




\begin{tabular}{|c|c|c|c|}
\hline 3. Skim & $\begin{array}{l}\text { Menerangkan kedudukan } \\
\text { kedai di skim perumahan } \\
\text { yang telah ditentukan. } \\
\text { Daripada rekod yang } \\
\text { diperolehi, sebanyak } 522 \\
\text { skim terlibat. } \\
\text { Walaubagaimanapun, } \\
\text { setelah membuat pelarasan } \\
\text { kedudukan skim, hanya } 161 \\
\text { skim sahaja yang tinggal. }\end{array}$ & Nominal & - \\
\hline $\begin{array}{l}4 . \\
\text { Klasifikasi } \\
\text { kawasan }\end{array}$ & $\begin{array}{l}\text { Menerangkan lokasi harta } \\
\text { tanah seperti berikut: } \\
\text { i. Utama Pusat Bandar } \\
\text { ii. Utama Luar Bandar } \\
\text { iii. Sekunder Pusat Bandar } \\
\text { iv. Sekunder Luar Bandar } \\
\text { v. Pedalaman }\end{array}$ & Nominal & $\begin{array}{l}\text { i. DKK101 } \\
\text { ii. DKK102 } \\
\text { iii. DKK103 } \\
\text { iv. DKK104 }\end{array}$ \\
\hline $\begin{array}{l}1 . \\
\text { Pegangan }\end{array}$ & $\begin{array}{l}\text { Status hakmilik pegangan } \\
\text { harta tanah iaitu: } \\
\text { i. Kekal } \\
\text { ii. Pajakan } 99 \text { tahun } \\
\text { iii. Pajakan } 60 \text { tahun }\end{array}$ & Nominal & DP_KEKAL \\
\hline $\begin{array}{l}\text { 2. Tarikh } \\
\text { pindah milik }\end{array}$ & Tarikh perjanjian jual beli & $\begin{array}{l}\text { Nisbah - diukur } \\
\text { mengikut } \\
\text { hari/bulan/tahun }\end{array}$ & $\begin{array}{c}\text { DT8-DT14 } \\
\text { DBH1-DBH2 } \\
\text { DBQ1-DBQ4 }\end{array}$ \\
\hline
\end{tabular}




\begin{tabular}{|c|c|c|c|c|}
\hline \multirow{6}{*}{$\begin{array}{l}\text { C. Pindah } \\
\text { milik }\end{array}$} & $\begin{array}{l}\text { 3. Syer } \\
\text { Pindah } \\
\text { milik }\end{array}$ & $\begin{array}{l}\text { Menunjukkan bahagian syer } \\
\text { yang dipindah milik }\end{array}$ & $\begin{array}{l}\text { Nisbah - diukur } \\
\text { dalam nombor }\end{array}$ & A_SYER \\
\hline & $\begin{array}{l}\text { 4. Pindah } \\
\text { milik } \\
\text { Pertama }\end{array}$ & $\begin{array}{l}\text { Menunjukkan sama ada } \\
\text { harta tanah dipindah milik } \\
\text { untuk kali pertama atau tidak. }\end{array}$ & Nominal & D_PMP \\
\hline & $\begin{array}{l}\text { 5. Status } \\
\text { Pembeli }\end{array}$ & $\begin{array}{l}\text { Status kewarganegaraan } \\
\text { pembeli }\end{array}$ & Nominal & PM1-PM4 \\
\hline & $\begin{array}{l}\text { 6. Status } \\
\text { Penjual }\end{array}$ & $\begin{array}{l}\text { Status kewarganegaraan } \\
\text { penjual }\end{array}$ & Nominal & PN1-PN4 \\
\hline & $\begin{array}{l}\text { 7. Nilai } \\
\text { yang } \\
\text { dilapor }\end{array}$ & $\begin{array}{l}\text { Nilai yang dilapor merujuk } \\
\text { kepada nilaian yang } \\
\text { dilaporkan oleh JPPH } \\
\text { kepada LHDN. Kadangkala } \\
\text { nilai yang dilapor adalah } \\
\text { sama dengan balasan dan } \\
\text { ada juga yang lebih tinggi } \\
\text { daripadanya. }\end{array}$ & $\begin{array}{l}\text { Nisbah - diukur } \\
\text { dalam Ringgit } \\
\text { Malaysia }\end{array}$ & - \\
\hline & $\begin{array}{l}\text { 8. Harga } \\
\text { Balasan }\end{array}$ & $\begin{array}{l}\text { Harga yang dipersetujui } \\
\text { antara pembeli dan penjual } \\
\text { serta terdapat dalam } \\
\text { perjanjian jual beli. }\end{array}$ & $\begin{array}{l}\text { Nisbah - diukur } \\
\text { dalam Ringgit } \\
\text { Malaysia }\end{array}$ & DV \\
\hline
\end{tabular}

\subsection{Keadaan Pasaran Harta Tanah Kedai Pra-Perang di Pulau Pinang (2014)}

Di peringkat awal, kajian ini telah mempertimbangkan penggunaan data pindah milik dari tahun 2005 hingga 2014 iaitu melibatkan 10 tahun. Walaubagaimanapun, data untuk 3 tahun terawal iaitu dari tahun 2005 hingga 2007 adalah tidak lengkap dari segi maklumat pemboleh ubah. Justeru kajian ini telah menggunakan data dari 2008 hingga 2014 sebagai sampel kajian. Jadual 3 di bawah menunjukkan statistik deskriptif pindah milik harta tanah kedai dari tahun 2008-2014: 
Jadual 3: Statistik Deskriptif Pindah Milik Harta Tanah Kedai dari Tahun 2008-2014 (Sumber: NAPIC, 2008-2014)

\begin{tabular}{|l|c|c|c|c|c|c|}
\hline \multicolumn{1}{|c|}{ Pemboleh Ubah } & Minimum & Maximum & Mean & Median & Mode & $\begin{array}{c}\text { Std. } \\
\text { Deviation }\end{array}$ \\
\hline Bilangan Tingkat & 1 & 4 & 2 & 2 & 2 & 0.548 \\
\hline Syer & 0.03 & 1.00 & 0.95 & 1.00 & 1.00 & 0.18 \\
\hline Luas Tanah (mp) & 13.00 & 498.00 & 147.34 & 130.00 & 130.00 & 61.70 \\
\hline Luas Bangunan (mp) & 13.00 & 1564.00 & 283.04 & 247.00 & 247.00 & 128.06 \\
\hline Umur Bangunan (Tahun) & 1.00 & 80.00 & 26.01 & 15.00 & 1.00 & 25.60 \\
\hline Harga Balasan (RM) & 27778.00 & 7500000.00 & 634918.94 & 453600.00 & 300000.00 & 563911.88 \\
\hline
\end{tabular}

Pulau Pinang menawarkan harta tanah kedai sedia ada sebanyak 30,200-unit seperti yang dipaparkan pada Rajah 1 iaitu mewakili $7.5 \%$ daripada keseluruhan penawaran kedai di seluruh Malaysia.

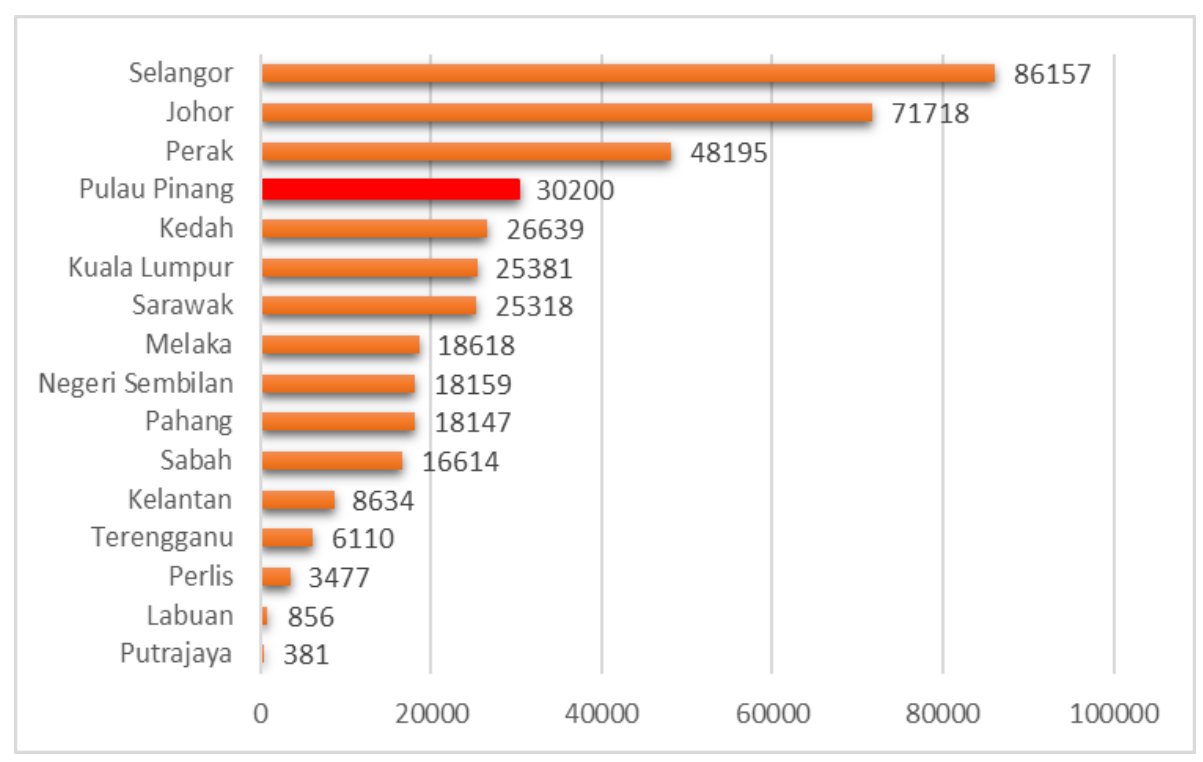

Rajah 1: Penawaran Sedia Ada Harta Tanah Kedai Mengikut Negeri 2014.

(Sumber: Laporan Pasaran Harta 2014, NAPIC)

Walaupun penawaran harta tanah kedai sedikit rendah di Pulau Pinang, namun penawaran harta tanah kedai pra-perang di Pulau Pinang merupakan kedua tertinggi selepas negeri Perak. Jumlah penawaran yang direkodkan ialah sebanyak 4,816 unit berbanding negeri Perak iaitu 5,798 unit seperti pada Rajah 2. Jumlah penawaran ini mewakili $20.0 \%$ daripada keseluruhan penawaran Kedai Pra-Perang yang terdapat di seluruh Malaysia. Ini menunjukkan bahawa Pulau Pinang merupakan salah satu lokasi utama di mana terletaknya harta tanah warisan yang paling banyak di Malaysia. 


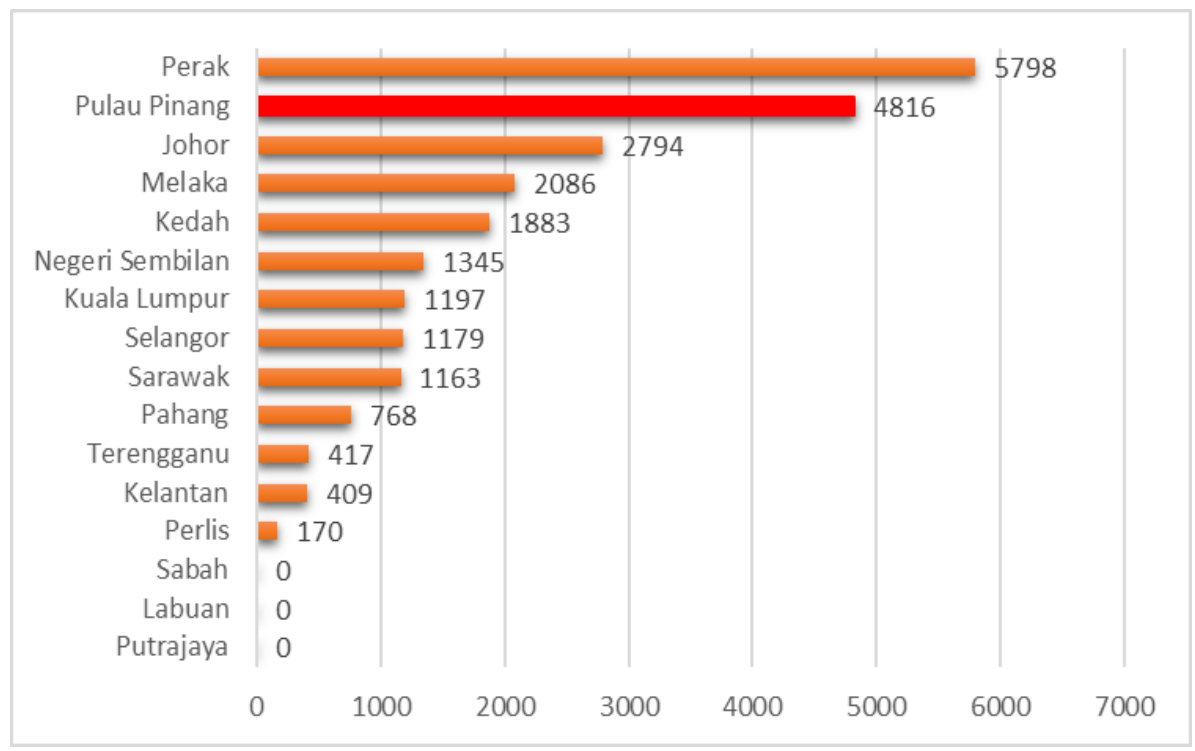

Rajah 2: Penawaran Sedia Ada Kedai Pra-Perang Mengikut Negeri 2014.

(Sumber: Laporan Pasaran Harta 2014, NAPIC)

Dari segi bilangan pindah milik, Pulau Pinang merupakan negeri ke enam tertinggi yang mencatatkan pindah milik harta tanah kedai dengan catatan sebanyak 1,401 unit $(7.0 \%)$ seperti yang ditunjukkan pada Rajah 3 pada tahun 2014.

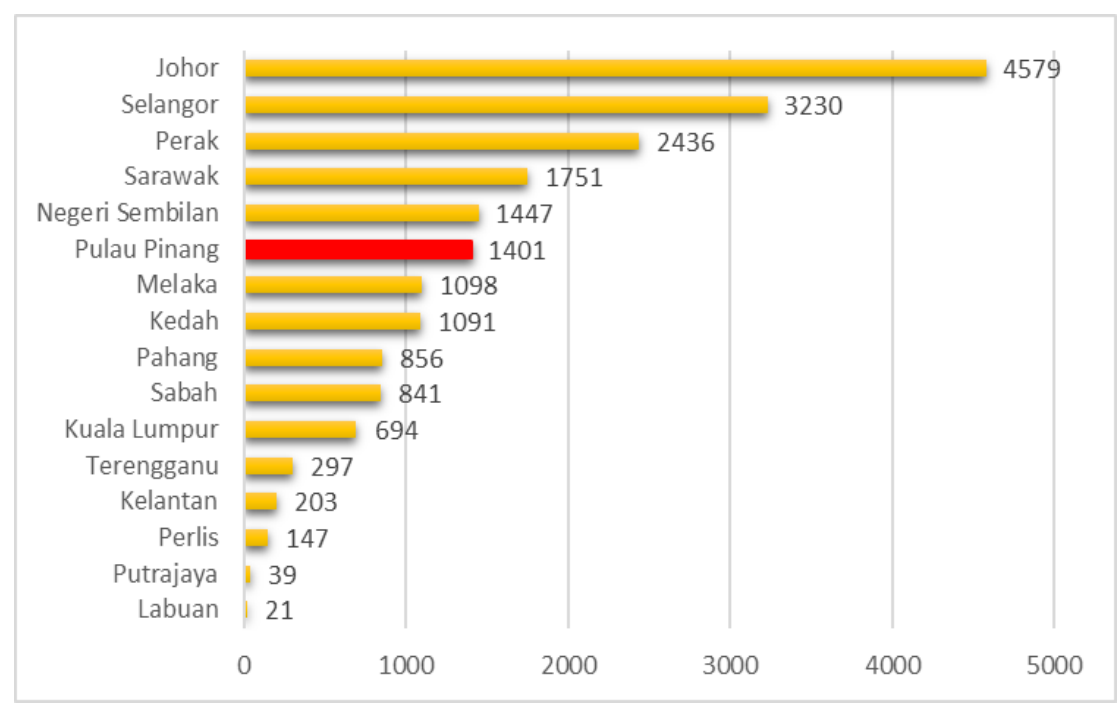

Rajah 3: Bilangan Pindah milik Harta Tanah Kedai Mengikut Negeri 2014.

(Sumber: Laporan Pasaran Harta 2014, NAPIC)

Walaubagaimanapun, Pulau Pinang mencatatkan pindah milik tertinggi untuk Kedai Pra-Perang pada 2014 dengan catatan 184 unit (28.0\%) seperti yang tertera pada Rajah 4. 


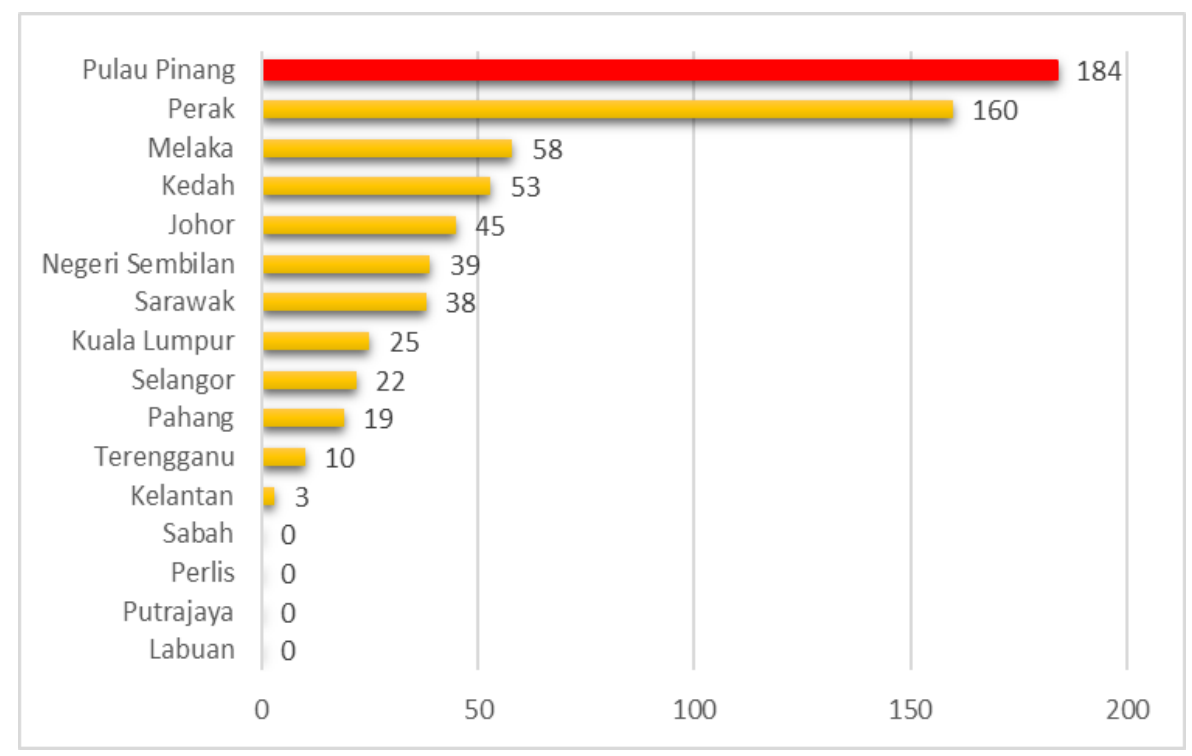

Rajah 4: Bilangan Pindah milik Kedai Pra-Perang Mengikut Negeri 2014.

(Sumber: Laporan Pasaran Harta 2014, NAPIC)

Situasi hampir juga sama berlaku dari segi nilai pindah milik di Pulau Pinang, di mana secara keseluruhan berada di kedudukan ke lima tertinggi dengan merekodkan RM1,121.04 juta (7.4\%) seperti pada Rajah 5.

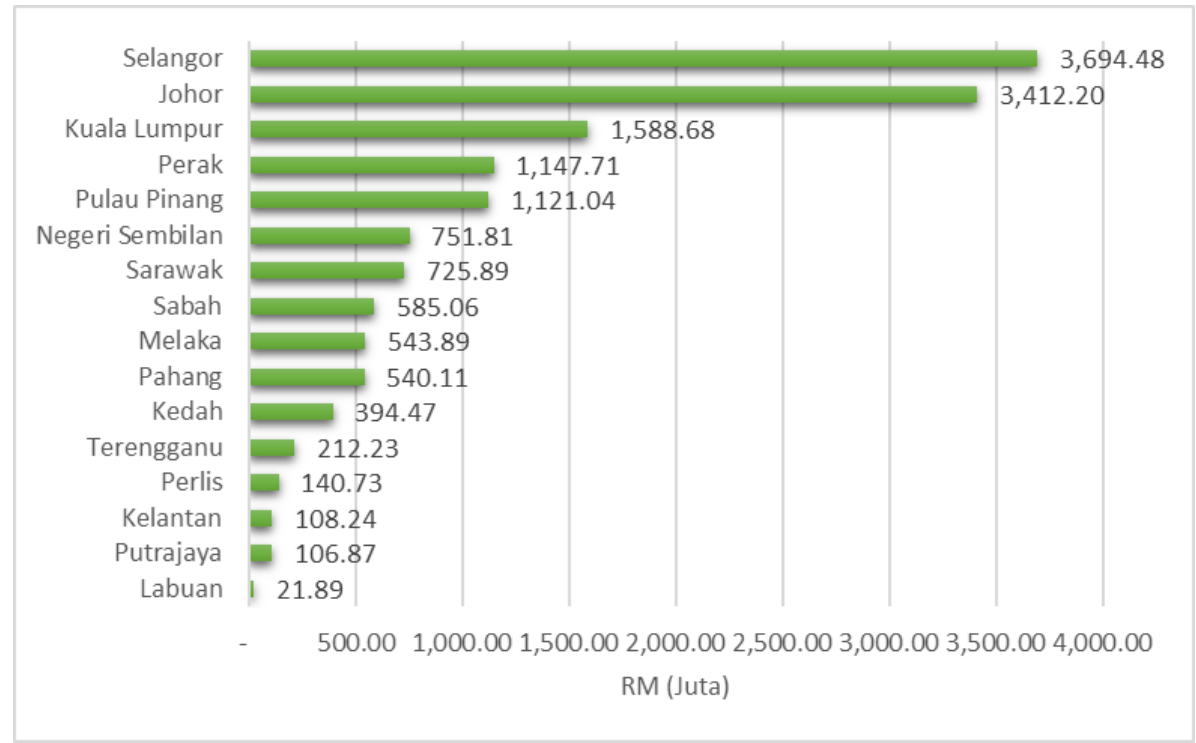

Rajah 5: Nilai Pindah Milik Harta Tanah Kedai Mengikut Negeri 2014.

(Sumber: Laporan Pasaran Harta 2014, NAPIC)

Namun seperti pada Rajah 6, Pulau Pinang mencatatkan nilai pindah milik tertinggi untuk Kedai Pra-Perang iaitu lebih sebahagian nilai dipindah milik di negeri ini sebanyak RM309.86 Juta (56.2\%). 


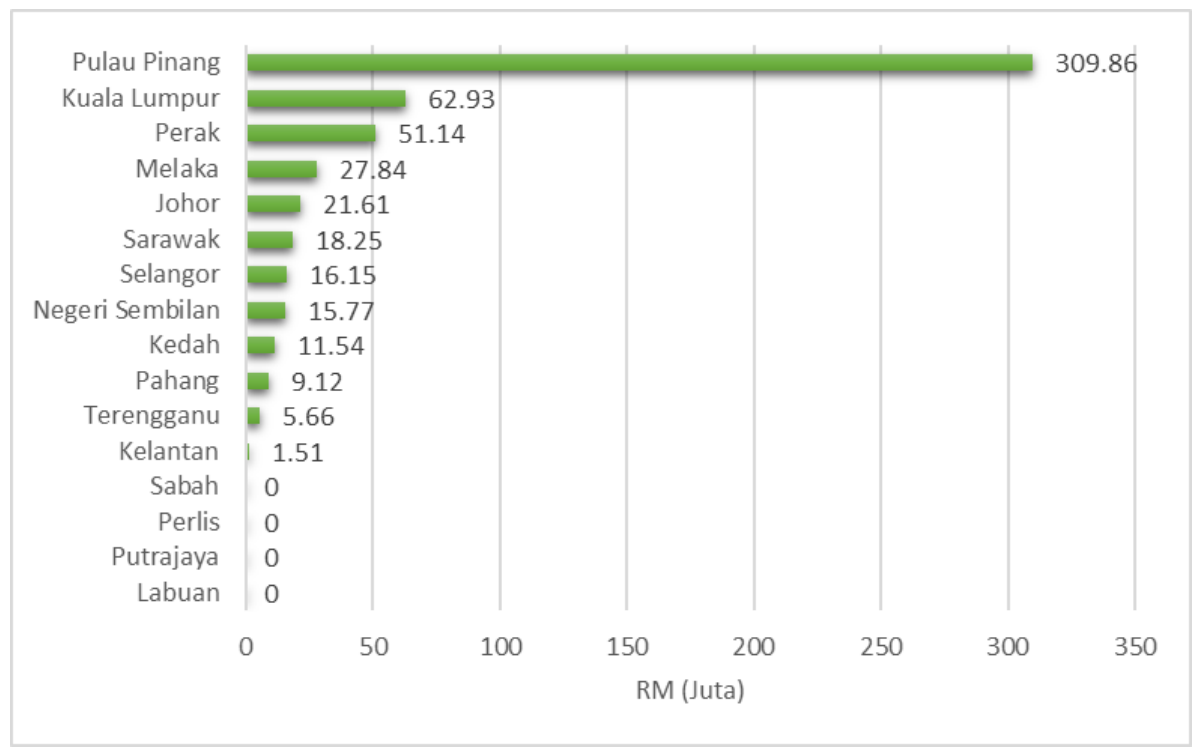

Rajah 6: Nilai Pindah milik Kedai Pra-Perang Mengikut Negeri 2014.

(Sumber: Laporan Pasaran Harta 2014, NAPIC)

Dari segi penawaran sedia ada sehingga ke bilangan dan nilai pindah milik, Pulau Pinang telah membuktikan bahawa pasaran harta tanah warisan yang diwakili oleh Kedai Pra-Perang adalah sangat aktif. Mengikut Laporan The Star bertarikh 12 Jun 2016 menyatakan kebanyakan pelabur luar negara cenderung untuk membuat pelaburan pada kedai pra-perang di Pulau Pinang terutama di George Town. Justeru pemilihan negeri Pulau Pinang sebagai kawasan kajian sangat bertepatan dan bersesuaian bagi mewujudkan indikator harta tanah kedai pra-perang.

\subsection{Model Harga Hedonik Laspeyres}

Di Malaysia, kebanyakan pembangunan indeks harta tanah menggunakan Model Harga Hedonik dengan Teknik Laspeyres. Perkara ini boleh dilihat pada Jadual 1. Model Hedonik Laspeyres hanya menggunakan model teras pemboleh ubah tidak bersandar dan mengabaikan pemboleh ubah andaian masa. Teknik ini membolehkan anggaran parameter berbeza dianggarkan pada setiap tahun dan memerlukan model berasingan bagi setiap tempoh kajian. Formula model ini adalah seperti berikut:

$$
\ln P=\beta_{0}+\beta_{1} X_{1}+\ldots \ldots \ldots \ldots+\beta_{n} X_{n}+\varepsilon_{0}
$$

Di mana;

In $P \ldots \ldots \ldots$ mewakili harga balasan harta tanah kedai dalam bentuk log.

Penukaran pemboleh ubah bersandar dalam bentuk log

menjadikan persamaan ini menjadi semi log. Penukaran

pemboleh ubah bersandar kepada nilai log bertujuan untuk 
mendapatkan normaliti data.

$X_{1} \ldots \ldots X_{n}$ mewakili vektor $\mathrm{n}$ pemboleh ubah tidak bersandar seperti yang diterangkan pada Jadual 2;

$\beta$ mewakili vektor parameter yang dianggarkan

$\varepsilon$ mewakili vektor istilah ralat rawak (“random error terms")

Dengan menggunakan kaedah ini, pemboleh ubah masa diabaikan dalam pembentukan fungsi persamaan. Sebaliknya anggaran parameter diperolehi dengan menganggarkan regresi berasingan bagi setiap tahun. Pada masa yang sama, ia juga perlu untuk menentukan pemberat bagi tahun asas iaitu purata pemboleh ubah kuantitatif yang diambil kira dalam pembentukan model dan peratusan pemboleh ubah kualitatif.

Bagi tujuan pengiraan PW-SPI, Teknik Laspeyres telah digunakan. Menurut Fisher et al (2007) kelebihan teknik ini adalah kuantiti data hanya dapat dilihat dari tempoh rujukan atau pada tahun asas. Ini memberi kita perbandingan yang lebih bermakna dan tepat dari masa ke masa. Justeru, perubahan dalam indeks boleh dikaitkan dengan perubahan harga. Ini kerana ia merupakan teknik yang paling diterima pakai dalam pembangunan indeks harta tanah di Malaysia iaitu IHRM dan PBORI (yang diterbitkan oleh NAPIC). Selain itu, Aina Edayu (2015) turut mengguna pakai teknik ini dalam pembangunan indeks harta tanah pejabat yang diberi nama KL-OPI.

Bagi teknik Laspeyres, pemboleh ubah andaian masa tidak dimasukkan dalam persamaan dan data diregresi mengikut setiap tempoh kajian daripada tahun 2008 hingga 2014. Indeks yang dijana daripada teknik ini juga dikenali sebagai indeks "berpemberat-asas" atau "berpemberat-tetap" kerana perubahan harga berpemberat dari segi kuantiti dalam tempoh asas. Dalam hal ini, tahun asas adalah 2008. Formula untuk mengira indeks Laspeyres adalah seperti berikut:

$$
P I_{t}=100\left(\begin{array}{l}
e^{\beta_{t} X_{0}} \\
e^{\beta_{0} X_{0}}
\end{array}\right)
$$

dimana

$P I_{t} \ldots \ldots \ldots \ldots$ mewakili indeks harga bagi sesuatu tahun

$\beta_{0} \ldots \ldots \ldots \ldots$ mewakili pekali regresi model hedonik tahun asas yang

ditetapkan iaitu 2008

$\beta_{t} \ldots \ldots \ldots \ldots$ mewakili pekali regresi model hedonik tahun semasa

$\mathrm{X}_{0} \ldots \ldots \ldots \ldots$ mewakili purata pemboleh ubah lot-lot kedai yang terjual pada 
tahun asas 2008

Indeks Harga Kedai Pra-Perang Pulau Pinang (PW-SPI) yang dibangunkan

Kedai Pra-Perang telah wujud di pasaran harta tanah sejak sebelum merdeka lagi. Di samping usianya yang menggambarkan elemen warisan, senibina arkiteknya juga menggambarkan bahawa Kedai Pra-Perang ini mempunyai elemen warisan. Justeru kajian ini telah membangunkan PW-SI menggunakan kaedah pindahmilik hedonik Laspeyres. Hasil regresi adalah seperti Jadual 4. Antara elemen utama yang boleh diberi penekanan ialah Produks, Indeks, pertumbuhan dan pemberat 2008. Produks ialah purata harga kedai dalam bentuk logaritma. Indeks pula ialah bacaan mata indeks atau penanda aras hasil daripada nilai produk. Pertumbuhan ialah kadar perubahan yang berlaku antara dari tahun sekarang berbanding tahun sebelum. Manakala pemberat 2008 pula ialah purata setiap pemboleh ubah yang telah ditetapkan sebagai tahun asas.

Jadual 4: Hasil Regresi PW-SPI Pulau Pinang

\begin{tabular}{|c|c|c|c|c|c|c|c|c|}
\hline \begin{tabular}{|l|} 
Tahun \\
Pemboleh Ubah \\
\end{tabular} & 2008 & 2009 & 2010 & 2011 & 2012 & 2013 & 2014 & \begin{tabular}{c|} 
Pemberat \\
2008
\end{tabular} \\
\hline Intercept & 11.356 & 14.723 & 9.639 & 12.179 & 10.236 & 11.668 & 8.167 & \\
\hline DM154 & 0.517 & 0.140 & 1.569 & 1.056 & 0.049 & 0.185 & 0.926 & 0.984 \\
\hline DP KEKAL & 0.220 & 0.000 & 0.660 & 0.000 & 0.608 & 0.000 & 0.000 & 0.992 \\
\hline DKK101 & 0.000 & 0.151 & 0.000 & -0.157 & 0.274 & 0.000 & 0.000 & 0.220 \\
\hline DKK103 & -0.280 & 0.000 & -0.081 & -0.277 & 0.048 & -0.130 & 0.077 & 0.780 \\
\hline DKK104 & 0.000 & 0.000 & 0.000 & 0.000 & 0.000 & 0.000 & 0.000 & 0.000 \\
\hline DBH1 & 0.006 & -0.265 & -0.043 & 0.036 & -0.205 & -0.113 & -0.180 & 0.449 \\
\hline A_TINGKAT & 0.000 & 0.000 & 0.000 & 0.000 & 0.000 & 0.000 & 000 & 2.000 \\
\hline A_SYER & 1.794 & 1.519 & 1.209 & 1.720 & 1.271 & 1.485 & 1.894 & 0.937 \\
\hline A_LTNH & 0.002 & 0.002 & 0.002 & 0.005 & 0.003 & 0.002 & 0.003 & 134.500 \\
\hline A LBGN & 0.000 & 0.000 & 0.000 & 0.000 & 0.000 & 0.001 & 0.001 & 259.294 \\
\hline A_UMUR & -0.013 & -0.054 & -0.002 & -0.026 & 0.016 & 0.001 & 0.036 & 67.339 \\
\hline PM4 & 0.207 & -0.097 & 0.146 & -0.095 & -0.015 & 0.190 & -0.143 & 0.315 \\
\hline PN4 & 0.268 & 0.318 & 0.289 & 0.147 & 0.334 & 0.188 & 0.310 & 0.213 \\
\hline Produk & 13.020 & 12.992 & 13.218 & 13.371 & 13.581 & 13.784 & 13.774 & \\
\hline Indeks & 100.0 & 97.2 & 121.9 & 142.0 & 175.2 & 214.6 & 212.4 & \\
\hline Pertumbuhan & & $-2.8 \%$ & $25.4 \%$ & $16.5 \%$ & $23.4 \%$ & $22.5 \%$ & $-1.0 \%$ & \\
\hline
\end{tabular}

Rajah 7 menunjukkan hasil daripada analisis regresi untuk kedai pra-perang di Pulau Pinang. Secara keseluruhannya, PW-SPI membolehkan perbandingan dibuat di antara harta tanah yang berbeza jenis. Sebagai contoh, Rajah 7 menunjukkan pertumbuhan yang lebih tinggi berbanding dengan Kedai Bukan Pra-Perang (NPW-SPI) seperti dalam Rajah 7. Perkara ini menunjukkan bahawa Kedai Pra-Perang mempunyai nilai pertumbuhan harga yang lebih tinggi berbanding dengan Kedai Bukan PraPerang.Perbandingan sebegini boleh membantu bakal pelabur membuat keputusan untuk memilih harta tanah yang lebih berpotensi sebagai pelaburan. 


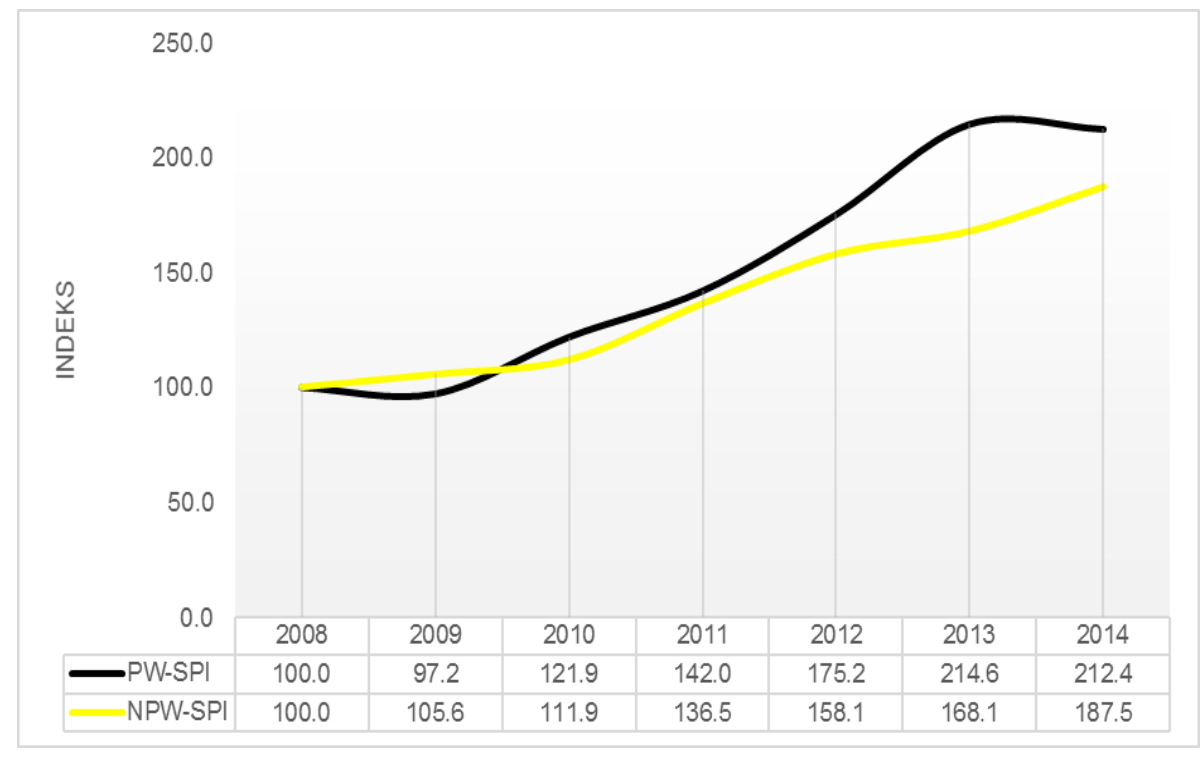

Rajah 7: Perbandingan PW-SPI dan NPW-SPI Pulau Pinang

Berdasarkan maklumat ini perbandingan ringkas boleh dibuat dengan kedai bukan Pra-Perang (NPW) bagi mengesan sekiranya terdapat perbezaan pertumbuhan harga antara kedua-keduanya. Jadual 5 menunjukkan bagaimana indeks untuk NPW-SPi diperolehi.

Jadual 5: Hasil Regresi NPW-SPI Pulau Pinang

\begin{tabular}{|c|c|c|c|c|c|c|c|c|}
\hline \begin{tabular}{c|} 
Tahun \\
Pemboleh Ubah
\end{tabular} & 2008 & 2009 & 2010 & 2011 & 2012 & 2013 & 2014 & $\begin{array}{c}\text { Pemberat } \\
2008\end{array}$ \\
\hline Intercept & 9.982 & 10.069 & 10.313 & 10.846 & 10.531 & 10.471 & 10.943 & \\
\hline DM154 & 0.745 & 0.816 & 0.764 & 1.148 & 1.089 & 1.201 & 1.074 & 0.096 \\
\hline DP_KEKAL & -0.210 & -0.160 & -0.349 & -0.159 & -0.046 & -0.033 & -0.228 & 0.964 \\
\hline DKK101 & 0.212 & 0.273 & 0.457 & 0.273 & 0.266 & 0.276 & 0.375 & 0.255 \\
\hline DKK103 & 0.090 & 0.099 & 0.193 & 0.083 & 0.119 & 0.106 & 0.161 & 0.450 \\
\hline DKK104 & -0.223 & -0.191 & -0.052 & -0.189 & -0.073 & -0.142 & 0.000 & 0.109 \\
\hline DBH1 & 0.048 & -0.030 & -0.035 & -0.120 & -0.021 & -0.018 & -0.026 & 0.496 \\
\hline A_TINGKAT & 0.184 & 0.228 & 0.128 & 0.045 & 0.142 & 0.200 & 0.095 & 2.337 \\
\hline A_SYER & 1.781 & 1.656 & 1.827 & 1.588 & 1.619 & 1.640 & 1.542 & 0.937 \\
\hline A_LTNH & 0.003 & 0.003 & 0.003 & 0.002 & 0.003 & 0.003 & 0.003 & 143.185 \\
\hline A_LBGN & 0.001 & 0.001 & 0.001 & 0.001 & 0.001 & 0.000 & 0.001 & 285.426 \\
\hline A_UMUR & -0.004 & -0.008 & -0.011 & -0.012 & -0.010 & -0.011 & -0.011 & 14.326 \\
\hline PM4 & -0.092 & -0.015 & -0.025 & 0.093 & 0.107 & 0.089 & 0.036 & 0.556 \\
\hline PN4 & 0.173 & 0.142 & 0.094 & 0.105 & 0.106 & 0.116 & 0.106 & 0.219 \\
\hline Produk & 12.669 & 12.723 & 12.781 & 12.980 & 13.127 & 13.188 & 13.297 & \\
\hline Indeks & 100.0 & 105.6 & 111.9 & 136.5 & 158.1 & 168.1 & 187.5 & \\
\hline Pertumbuhan & & $5.6 \%$ & $6.0 \%$ & $22.0 \%$ & $15.8 \%$ & $6.3 \%$ & $11.5 \%$ & \\
\hline
\end{tabular}

Merujuk Rajah 7, PW-SPI sedikit menguncup pada kadar 2.8\% berbanding NPW-SPI yang menunjukkan pertumbuhan positif. Walau bagaimanapun pada 2010, pertumbuhan PW-SPI melonjak lebih tinggi berbanding NPW-SPI dengan mencatatkan bacaan indeks 121.9 (25.4\%). Corak pertumbuhan ini terus menunjukkan nilai positif sehingga 2013 dan menunjukkan pertumbuhan yang lebih baik berbanding NPW-SPI. Walaupun pada tahun 2014 PW-SPI sedikit menurun dengan kadar 1.0\% kepada 212.4 mata, namun dari segi pertumbuhan keseluruhan PW-SPI masih lebih tinggi 
berbanding NPW-SPI. Menurut EdgeProp (2012), peningkatan pelancong dari luar negara menjadi salah satu kunci utama dimana permintaan terhadap harta tanah kedai pra-perang meningkat di Pulau Pinang sekitar tahun 2010 hingga 2013. Kebanyakan pelabur ini terutama dari Singapura lebih cenderung melabur dalam harta tanah kedai pra-perang kerana mempunyai warisan seni bina pesona lama yang unik dengan pengaruh timur dan barat (EdgeProp, 2016). Rajah 8 di bawah pula menunjukkan perbandingan pertumbuhan indeks antara PW-SPI dan NPW-SPI.

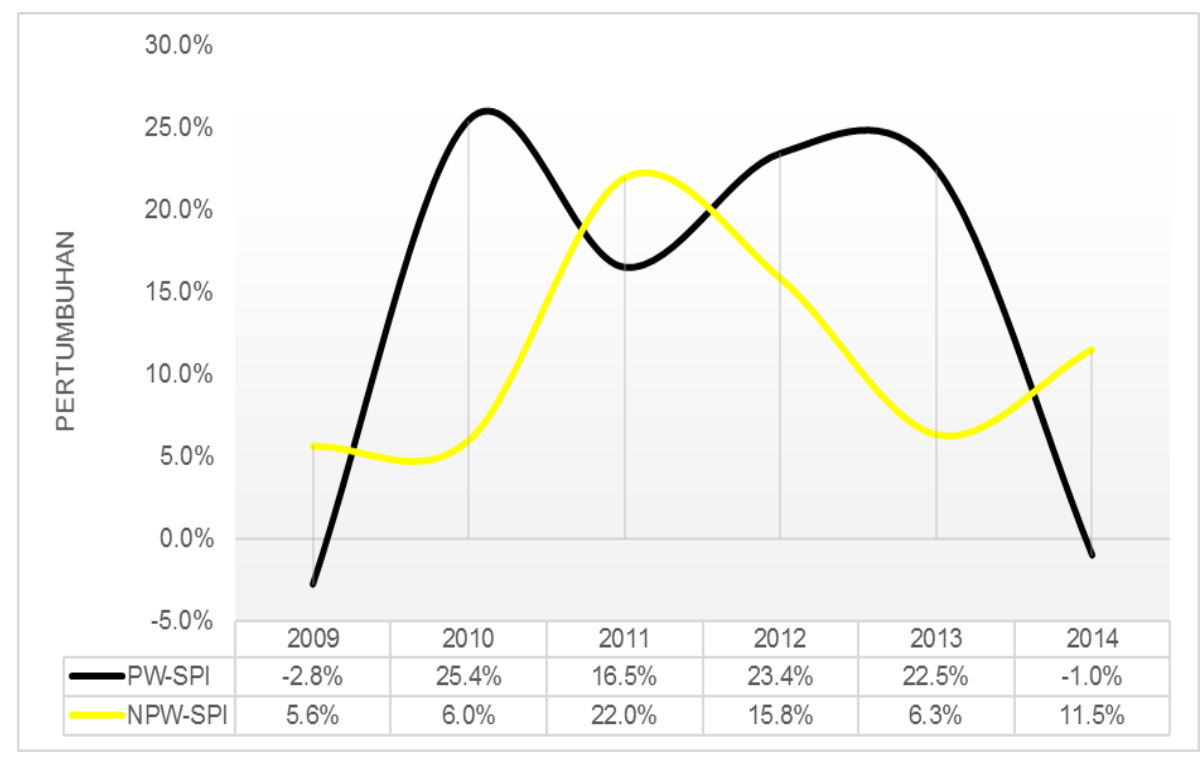

Rajah 8: Perbandingan Pertumbuhan PW-SPI dan Kedai Bukan Pra-Perang

\section{Perbincangan}

Kajian yang dilaksanakan ini merupakan antara perintis kepada pembangunan indeks harga harta tanah warisan di Malaysia, khususnya pada indeks harga kedai pra-perang di Pulau Pinang. Ini menjadikannya bukan sahaja antara penyelidikan terawal berkaitan harta tanah perdagangan yang dilakukan di negara ini tetapi juga di kalangan beberapa yang pertama di rantau ini.

Dengan adanya PW-SPI, tiada lagi isu berkenaan tiadanya indikator harga yang berkait dengan harta tanah warisan. Di harap kajian ini akan lebih diperluas di seluruh negara bagi mewujudkan Indeks Harga Harta Tanah Kedai Pra-Perang Malaysia. Maka, perbandingan dapat dilaksanakan mengikut negeri. Kewujudan PW-SPI ini mengurangkan jurang dalam pasaran harta tanah, di mana pada masa ini hanya mempunyai indikator harga harta tanah kediaman sahaja. la juga menunjukkan secara empirikal bahawa elemen warisan merupakan antara faktor terpenting dalam mempengaruhi nilai harta tanah di Malaysia khususnya di Pulau Pinang.

PW-SPI juga akan dapat membantu dan lebih meyakinkan para pelabur dari dalam mahupun luar negara bagi membuat keputusan untuk melabur dalam sektor harta tanah 
perdagangan di Malaysia terutama kedai pra-perang. Para pelabur juga tidak perlu merasa sangsi mahupun was-was untuk membuat pelaburan dalam sektor ini kerana terbukti dalam kajian ini harta tanah kedai pra-perang mempunyai pertumbuhan yang lebih baik dan menjanjikan pulangan yang lebih lumayan.

\subsection{Kesimpulan}

Kajian literatur menunjukkan bahawa masih belum ada petunjuk, indikator atau penanda aras yang telah dibangunkan yang dapat menggambarkan prestasi dan trend harta tanah warisan khususnya di Malaysia. PW-SPI merupakan indikator pertama yang dibangunkan berkaitan harta tanah warisan di Malaysia. Hasil kajian ini membolehkan perbandingan secara grafik dilakukan bagi melihat perbezaan pertumbuhan harga harta tanah yang berbeza. Secara khusus, hasil kajian menunjukkan harta tanah warisan yang diwakili oleh Kedai Pra-Perang mempunyai pertumbuhan yang lebih tinggi berbanding Kedai Bukan Pra-Perang, walaupun kedai ini telah lama wujud. Indikator prestasi ini sangat penting bagi membantu para pelabur dalam membuat keputusan untuk melabur dalam harta tanah warisan. Dengan adanya penglibatan para pelabur dalam sektor harta tanah warisan, ia akan membantu Malaysia dalam mengekalkan ciri-ciri warisan selari dengan arus pembangunan yang pesat. Hasil kajian ini telah menghasilkan indeks yang boleh dirujuk sebagai gambaran pertumbuhan harga harta tanah warisan di Pulau Pinang. la merupakan asas yang boleh digunakan oleh pihak pembangun indeks harta tanah dalam mengambilkira elemen warisan sebagai petunjuk pembangunan ekonomi.

\section{Rujukan}

Aina Edayu, A. (2015). Development of Kuala Lumpur Office Price Index (KL-OPI): An Application of Hedonic Price Model. (Tesis Sarjana) Fakulti Alam Bina, Universiti Malaya.

Akta Warisan Kebangsaan, Akta 645 (National Heritage Act) 2005.

Bailey, M. J., Muth, R. F., dan Nourse, H. O. (1963). A regression method for real estate price index construction. Journal of the American Statistical Association, 58, 933-942.

Bokhari, S. dan Geltner, D. (2010). Estimating real estate price movements for high frequency tradable indexes in a scarce data environment. Journal of Real Estate Finance and Economics, 45(2), 522-543.

Boudry, W. I., Coulson N. E., Kallberg J. G. \& Liu C. H. (2013). On Indexing Commercial Real Estate Properties and Portfolios. The Journal of Real Estate Finance and Economics, 47, 617-639.

Bursa Malaysia (2014). Bursa Malaysia Index Series. Di perolehi daripada https://www.bursamalaysia.com/trade/our_products_services/indices/bursa_malaysia_index _series

Case, K. E. dan Shiller, R. J. (1987). Prices of single-family homes since 1970: New indexes for four cities. National Bureau of Economic Research Cambridge, Massachusetts, USA. 
EdgeProp (2012). Henry Butcher: 'Cautiously optimistic' Penang residential market in 2012. Diperolehi daripada https://www.edgeprop.my/content/henry-butcher-cautiouslyoptimistic-penang-residential-market-2012.

EdgeProp (2016). Pre-war heritage property prices at all-time high: Henry Butcher Penang. Diperolehi daripada https://www.edgeprop.my/content/904921/pre-war-heritage-propertyprices-all-time-high-henry-butcher-penang

Farragher, E.J. and Savage, A. (2008). An investigation of real estate investment decisionmaking practices. Journal of Real Estate Practice and Education, 11(1), 29-40.

Fatin Afiqah Md Azmi, Suriatini Ismail, Normayuni Mat Zin, Nurul Hana Adi Maimun, Junainah Mohamad (2019). A Systematic Review On Spatial-Based Valuation Approach For Built Cultural Heritage. International Journal of Real Estate Studies, Vol 13(2)/2019, 59-70, ISBN 1832-8085

Fisher, J. D., Geltner, D. dan Pollakowski, H. (2007). A quarterly transactions-based index (TBI) of institutional real estate investment performance and movements in supply and demand. Journal Real Estate Finance and Economics, 34, 5-33.

Francke, M. K. (2010). Repeat Sales Index for Thin Markets. Journal of Real Estate Finance and Economics, July 2010, 41(1), 24-52.

Gatzlaff, D. H. dan Haurin, D. R. (1998). Sample selection and biases in local house value indices. Journal of Urban Economics, 43(2), 199-222.

Geltner, D., dan Pollakowski, H. (2006). A set of indexes for trading commercial real estate based on the Real Capital Analytics database. Retrieved from http://web.mit.edu/cre/research/credl/rca.html

Griliches, Z. (1971). Hedonic price indexes of automobiles: an econometric analysis of quality change. Cambridge University Press.

Haurin, D. R. (2003). US commercial real estate indices: transaction-based and constantliquidity indices. BIS Paper No. 21, 232-242.

Henry Butcher Malaysia (Penang) (2016). Penang Real Estate Market Q2 2016. Diperolehi daripada http://www.henrybutcherpenang.com/

Junainah Mohamad, Suriatini Ismail, Abdul Hamid Mar Iman, Thuraiya Mohd (2019). Testing the Use of Multiple Regression Analysis and Rank Transformation Regression for Heritage Property Valuation, Asian Journal of Quality of Life (AjQoL), 4(15) Jan / Apr 2019 (p.4262)

Junainah Mohamad, Suriatini Ismail \& Rosdi Abdul Rahman (2014a). Valuation of Cultural Heritage Asset: Issues and Challenges. TENIAT (International Journal of Creative Futures and Heritage). Vol 2(1): p64-75

Junainah Mohamad, Suriatini Ismail \& Rosdi Abdul Rahman (2014b). The Need to Improve Existing Method of Valuation for Cultural Heritage Asset. In R. Amoeda, S. Lira, \& Cristina 
Pinheiro (Eds.), Proceedings of the 4th International Conference on Heritage and Sustainable Development (pp. 463-472). (e-book ISBN 978-989-98013-7-0). Guimaraes, Portugal: Green Lines Institute for Sustainable Development

Junainah Mohamad, Suriatini Ismail, Rosdi Abdul Rahman \& Ahmad Rasdan Ismail (2015). Valuers' Perceptions on the Current Practice of Heritage Property Valuation in Malaysia. In 21st Annual Pacific-Rim Real Estate Society Conference. 18 - 21 January 2015. Kuala Lumpur

Junainah Mohamad, Suriatini Ismail \& Rosdi Abdul Rahman (2016). Valuing Historic Building Using Revealed Preference Method. 8th International Real Estate Research Symposium IRERS 2016. Putra World Trade Centre (PWTC), Kuala Lumpur, 26-28 April 2016.

Kementerian Kewangan Malaysia (MOF) (2017). Laporan Ekonomi.

Malaysian Institute of Economics Research (MIER). Residential Property Index 2003.

Mohamad Hafiz Jamaludin (2020). Pembangunan Indeks harga Kedai Pulau Pinang Dalam Tapak Warisan Dunia. Tesis Sarjana. Universiti Malaysia Kelantan.

Munneke, H. J. Dan Slade, B. A. (2001). A metropolitan transaction-based commercial price index: a time-varying parameter approach. Real Estate Economics, 29, 55-84.

Murzyn-Kupisz, M. (2013). The socio-economic impact of built heritage projects conducted by private investors. Journal of Cultural Heritage, 14(2), 156-162.

Norliza N. (2013). Penilaian Harta Tanah Warisan. Kertas Penyelidikan INSPEN, 2014.

Normayuni Mat Zin, Suriatini Ismail, Fatin Afiqah Azmi (2018). Ascertaining the Economic Sustainability of Heritage Property Market based on Sales Transaction Analysis, Environment-Behaviour Proceedings Journal, Vol 3(7), 247-254

Normayuni Mat Zin, Suriatini Ismail, Junainah Mohamad, Nurul Hana Adi Maimun, Fatin Afiqah Md. Azmi (2019). Critical Determinants Of Heritage Property Value: A Conceptual Framework Planning Malaysia, Vol 17(1) p.219-231

Osman, K. A. (2018). Heritage conservation management in Egypt: A review of the current and proposed situation to amend it. Ain Shams Engineering Journal, 9(4), 2907-2916.

Pagiola, S (2001). Valuing the Benefits of Investments in Cultural Heritage: The Historic Core of Split. Presented at the International Conference on Economic Valuation of Cultural Heritage Cagliari,19-20 October 2001.

Pusat Maklumat Harta Tanah Negara (NAPIC) (2012). Laporan Indeks Sewaan Pejabat Binaan Khas Wilayah Persekutuan Kuala Lumpur (WPKL). Jabatan Penilaian dan Perkhidmatan Harta, Kementerian Kewangan Malaysia.

Pusat Maklumat Harta Tanah Negara (NAPIC) (2014). Laporan Pasaran Harta 2005-2014. Jabatan Penilaian dan Perkhidmatan Harta, Kementerian Kewangan Malaysia. 
Pusat Maklumat Harta Tanah Negara (NAPIC) (2018). Laporan Indeks Sewaan Pejabat Binaan Khas Lembah Klang, Johor Bahru \& George Town, Suku 1 dan 2 2018. Jabatan Penilaian dan Perkhidmatan Harta, Kementerian Kewangan Malaysia.

Pusat Maklumat Harta Tanah Negara (NAPIC) (2018). Laporan Indeks Harga Rumah Malaysia, Suku 1 dan 2 2018. Jabatan Penilaian dan Perkhidmatan Harta, Kementerian Kewangan Malaysia.

Quigley, J. M. (1995). A simple hybrid model for estimating real estate price indexes. Journal of Housing Economics, 4, 1-12.

Reeve, A. \& Shipley, R. (2014). The impact of heritage investment on public attitudes to place: evidence from the Townscape Heritage Initiative (THI). Urban, Planning and Transport Research: An Open Access Journal, 2(1), 289-311.

Rosen, S. (1974). Hedonic prices and implicit markets: product differentiation in pure competition. The Journal of Political Economy, 82(1), 34-55.

The Star (2016). Foreigners 'invading' pre-war properties in Penang. Diperolehi daripada https://www.thestar.com.my/news/nation/2016/06/12/foreigners-invading-prewar-

properties-in-penang/ 